\title{
Research Based on China's Foreign Exchange Reserve Management
}

\author{
Juan Zhong ${ }^{1}$, Wuyue Chai ${ }^{2 *}$, Yaqing Liu ${ }^{3}$ \\ ${ }^{1}$ School of International Economics and Trade, Anhui University of Finance and Economics \\ ${ }^{2}$ School of Finance, Anhui University of Finance and Economics \\ ${ }^{3}$ School of Economics, Anhui University of Finance and Economics, Bengbu 233000, Anhui, China \\ Email: 1430649553@qq.com
}

\begin{abstract}
Through the understanding of foreign exchange reserves and the understanding of China's foreign exchange reserve management issues, this article establishes an econometric model to explore the factors that affect China's foreign exchange reserves, analyzes China's deficiencies in foreign exchange reserve management, and puts forward suggestions for improvement. ${ }^{[1]}$ The study found that at this stage, China's foreign exchange reserves are large in scale, the dollar's share of foreign exchange reserves is adjusted year by year, and there is a large amount of room for improvement in earnings influences. Therefore, this article puts forward suggestions for the management of foreign exchange reserves according to the actual situation. The aim is to increase the strength and effectiveness of the management of foreign exchange reserves. This article will have a certain enlightening effect on the management of foreign exchange in China.
\end{abstract}

Keywords: foreign exchange reserves, management measures, econometric

\section{Introduction}

With the rapid development of China's economy and the continuous improvement of its international status, China's foreign exchange reserves are also on the rise. By the end of 2018, China's foreign exchange reserves had ranked first in the world for 13 consecutive years. Static foreign exchange reserve refers to payment means and assets expressed in foreign currencies that can be used for international liquidation. China's foreign exchange reserve is defined as broad foreign exchange, including foreign currency notes, foreign currency payment vouchers or payment instruments, foreign currency securities, Special Drawing Rights and other foreign exchange assets. Foreign exchange plays an important role in the development of a country. It can meet the needs of international payments, improve international credibility, and facilitate trade cooperation and capital flow between countries. At the same time, foreign exchange reserves can ensure the stability of a country's exchange rate, avoid a substantial devaluation of the local currency, and prevent a currency crisis. Analyzing the current situation of China's foreign exchange reserves and the management of foreign exchange reserves is helpful to optimize the structure of China's foreign exchange reserves, promote the national economic development and further enhance the overall national strength.

\section{Research on the influencing factors of China's foreign exchange serves}

\subsection{Variable setting}

This article selects the following six variables to discuss the influencing factors of foreign exchange reserves based on the status quo of China's foreign exchange reserves and theoretical knowledge research, which are explained variables: foreign exchange reserves y (100 million US dollars), explanatory variables: GDP x 1 (100 million US dollars), RMB to US dollar exchange rate x2 (US $\$=100$ ) (yuan), foreign debt balance $\mathrm{x} 3$ (US $\$ 100$ million), import and export balance $\mathrm{x} 4$ (US $\$ 100$ million), foreign direct investment x5 (US \$ 100 million).

According to the research and experience of various scholars on the factors affecting foreign exchange reserves, this article sets the model of factors affecting foreign exchange reserves.

The research data in this paper come from the National Bureau of Statistics, and the article sorts out and selects the statistical data of each variable from 1999 to $2018 .{ }^{[2]}$

\subsection{Least squares regression analysis}

This article uses econometrics methods and uses EViews 9 software to establish a linear regression model for the influencing factors of China's foreign exchange reserves. The results are as follows:

$$
\begin{aligned}
& \ln y=-8.0463-0.0022 \ln x 1-0.0042 \ln x 2-0.5484 \ln x 3+0.2828 \ln x 4+3.0088 \ln x 5 \\
& \mathrm{t}=(-0.6625)(-0.0024) \quad(-0.0026) \quad(-1.6666) \quad(2.2773) \quad \text { (2.6025) } \\
& R^{2}=0.9704 \quad \overline{R^{2}}=0.9599 \quad \mathrm{~F}=91.9937 \quad \mathrm{DW}=1.3859
\end{aligned}
$$


From the regression results, the model has a high coefficient of determination and a good model fitting effect. Therefore, the combination of the five factors of China's GDP, exchange rate level, external debt balance, import and export balance, and foreign direct investment on China's foreign exchange reserves Is remarkable. However, the t test of GDP, exchange rate level, and external debt balance cannot pass the test. ${ }^{[3]}$ The $\mathrm{P}$ value is greater than 0.05 , and the GDP has a reverse effect on foreign exchange reserves. This is in contradiction with the significance of economics, so the model may be There are multiple collinearity, heteroscedasticity or autocorrelation, this article will test the regression results.

\subsection{VIF inspection}

Since there may be a high degree of correlation between variables in the selection of variables, this article will explore the multicollinearity of the model through the VIF test. The VIF test needs to establish an auxiliary regression model for each explanatory variable and find the coefficient of determination. Calculated variance expansion factor $V I F_{i}=\frac{1}{1-R_{i}^{2}}$ false. When $>10$, it indicates that the regression equation has serious multicollinearity. The result of obtaining the variance expansion factor is as follows.

Table 1. VIF inspection results

\begin{tabular}{ccc}
\hline Variable & R-squared & \\
\hline $\ln x 1$ & 0.9957 & 232.5581 \\
$\ln x 2$ & 0.9242 & 13.1926 \\
$\ln x 3$ & 0.9654 & 28.9017 \\
$\ln x 4$ & 0.8641 & 7.3584 \\
$\ln x 4$ & 0.9883 & 85.4701 \\
\hline
\end{tabular}

It can be seen from the results that the variance expansion factor has 4 items greater than 10, and the model has more serious multicollinearity. This is mainly because all economic indicators can reflect the development and status of China's international status and economic strength. ${ }^{[4]}$ The rapid development of China's economy is reflected in the data of GDP and various trade indicators, so there is a high degree of correlation between variables.

\subsection{Heteroscedasticity test}

For different sample points, the variances of random error terms are different from each other, and then the model has heteroscedasticity. This will cause the parameter estimator to be ineffective and the variable t test to be meaningless, so this paper will use the White test to determine whether the model has heteroscedasticity. ${ }^{[5]}$ The auxiliary model established in this paper is as follows.

In the Eviews 9 software, the n obtained by the auxiliary regression model is progressively subject to a chi-square distribution with 9 degrees of freedom (with cross terms). Given a significance level of 0.05 , if $\mathrm{nR} 2<$, then the model has no heteroscedasticity, and the P value of nR2 $0.1349>0.05$, so there is no heteroscedasticity in the model.

\subsection{Model results}

After regression analysis and testing of the model, the model of influencing factors of foreign exchange reserves is obtained.

According to the model, we can know that China's foreign exchange reserves are mainly affected by foreign debt balance, import and export balance and foreign direct investment. Among them, the increase in foreign direct investment and export volume can increase China's foreign exchange reserves, while the increase in foreign debt balance will reduce China's foreign exchange reserves, Which is in line with economic significance. Therefore, China can better adjust foreign exchange reserves through these factors, and can also adjust the system of China's foreign exchange reserves to coordinate the impact of other factors on foreign exchange.

\section{Recommendations for the management of China's foreign exchange reserves}

\subsection{Strengthen the supervision of foreign exchange reserve risks}

Because foreign exchange reserves are composed of foreign currency assets of various countries and are mainly used to settle international payments, they will be affected by many factors, and there may be credit risk, liquidity risk, and operational risk. These influencing factors will cause the loss of China's foreign exchange reserves, so strengthening the supervision of foreign exchange reserve risks is a must to manage foreign exchange reserves. Therefore, China should strengthen the strict management of foreign exchange authorization and approval procedures. At the same time, increase the recognition of foreign exchange reserve risks,

3.2 Maintain the rationality of the foreign exchange reserve structure and the independence of monetary policy 
China is constantly adjusting the structure of its foreign exchange reserves, which is conducive to resisting risks. China should increase its efforts to adjust the structure of foreign exchange reserves, enrich the diversity of foreign exchange reserves, and control losses in various risks. At the same time, China must ensure the independence of its monetary policy and better stabilize its domestic assets under the condition of exchange rate fluctuations. ${ }^{[6]}$

\section{Conclusion}

As China's international status is getting higher and higher, and its economic strength is getting stronger, China is also actively participating in international economic exchanges and strengthening foreign exchanges, so that all countries can jointly benefit from economic exchanges. Therefore, foreign exchange reserves are becoming more and more important for China's economic development, and the scale of China's foreign exchange reserves is also increasing. In this era of economic globalization, China must improve its management of foreign exchange reserves, ensure its ability to resist risks, strengthen economic development, and increase its profitability on the basis of ensuring the safety and liquidity of foreign exchange reserves. Use foreign exchange reserves to serve China's economic construction and promote the healthy development of the country.

\section{References}

[1] Wang Yajun, Zeng Gang. Effective management of foreign exchange reserves: theory and application. Shanghai Finance. 2018; (08): 10-18.

[2] Sheng Zhaomei. Analysis of the management of foreign exchange reserves in China. Nongjia yuan. $2019 ;$ (17): 175.

[3] Zhu Guoping, Fu Qiong, Wang Yuwei. Research on the evolution of foreign exchange reserve management theory. Economic Perspective. 2018; (10): 120-128.

[4] Li Haohao. Innovative research on China's foreign exchange reserve management model. Chinese Business Review. 2020; (03): 51-52.

[5] Yu Fenfen. Study on hierarchical management of China's foreign exchange reserves. Zhejiang University, 2011.

[6] Huang Fengmin. Research on the moderate scale and management of China's foreign exchange reserves. Xiamen Uiversity, 2014. 